International Journal of

Health, Medicine and

Nursing Practice

(IJHMNP)

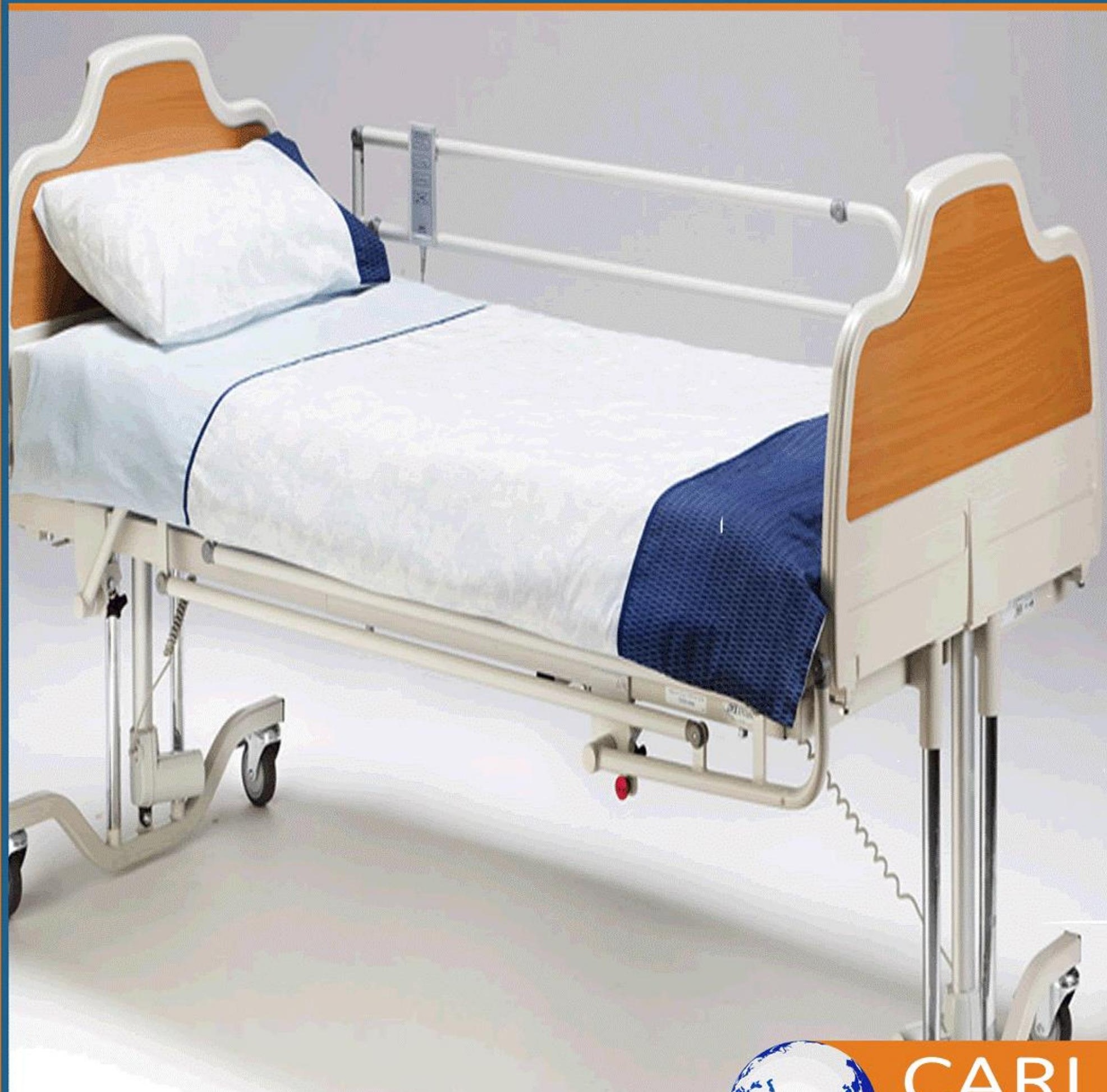




\title{
Knowledge, Attitude, And Practice Regarding Nursing Interruptions Among Nurses in Tertiary Care Hospital: A Cross- Sectional Study
}

\author{
${ }^{1 *}$ Simon Javed (Post RN BScN student) \\ Lahore School of Nursing, The University of Lahore \\ *Corresponding Author's Email: Simonjaved5063@gmail.com \\ 2* Muhammad Hussain \\ Associate Professor at LSN, The University of Lahore \\ *Corresponding Author's Email: Muhammad.hussain@1sn.uol.edu.pk \\ ${ }^{3}$ Kausar Parveen \\ Assistant professor at LSN, The University of Lahore, Lahore, Pakistan \\ ${ }^{4}$ Muhammad Afzal
}

Associate professor at LSN, The University of Lahore

\begin{abstract}
Purpose: Nursing is a profession who belong to care of community, a universal perception. Nurses job criteria belongs to many distractions and obstacles in performing their job. Interruption is considered to be part of workplace. The nursing profession responsibility and reliability are of high concerns because it deals with the life of human beings. Interruption at workplace compromises the patient safety. The study sought to explore the knowledge, attitude, and practices regarding nursing interruption among nurses.

Methodology: Descriptive cross-sectional study design used. Questionnaire a tool used to collect data from tertiary care hospital $(\mathrm{n}=115)$. The tool contains a dimension of knowledge attitude and practice scoring of questionnaires as knowledge 50 score, attitude 45 and practice 28, respectively number questions each domains knowledge 10, attitude 9 and practice 7.

Results: The KAP regarding interruption among Pakistani nurses score range (26-123). The means of knowledge attitude and practices respectively $31.2957 \pm 7.21229,33.1478 \pm 5.68507,19.5826$ \pm 3.86841 . the collective mean and standard deviation of knowledge attitude and practice 84.0261 \pm 16.76577. correlation statistically significant in KAP $(\mathrm{p}<0.05)$. Coefficient of correlation knowledge enhance practices. The combined KAP of respondents was $69 \%$.

Unique contribution to theory, practice and policy: Knowledge attitude and practice prime parameters of confirming the quality of understanding and performance. Study concluded that nurses have moderate level of knowledge attitude and practice $69 \%$. The knowledge and attitude positive coefficient correlation, enhance each other. Gender, increased academic qualification, attention of leader and experience correlation with KAP. Experience and age group 10-15 years possess a high degree of knowledge attitude and practice. There is a need for interruption
\end{abstract}


International Journal of Health, Medicine and Nursing Practice ISSN 2710-1150 (Online)

Vol. 3, Issue No. 2, pp 17- 35, 2021

$\underline{\text { www.carijournals.org }}$

management training moreover requiring leader attention. Basic understating about interruption on a clinical place not considerably efficient. The dependent variable causes a $20 \%$ variance in the criterion variable.

Keywords: Knowledge, Attitude, Practice, Nursing Interruptions, Nurses

\section{INTRODUCTION}

Nursing is a profession that belong to care the community, a universal perception. The process of care contains many steps that helps to achieve goals bases on major target. The job description of nurses belongs to periodic and regular tasks, but there are many turns in a circle where have to give pause to keep themselves move on. The regular task related to jobs harbors many turns which slow down objectives which are divided into parts. Interruptions come across in nursing due to the advancement of technology while the cognition level of human beings has not developed as technology is improved (Pepito \& Locsin, 2019).

The study on nursing interruption on workplace helps to identify the interruption and find strategy counter such temptations. Interruptions are considered as disruptive and distractive activity in workplace. There are many factors that promote interruptions consequently lead to disturbance in the flow process of professional activity (Monteiro, Avelar, \& Pedreira, 2015). The interruption if taken into positive impact making work more complex but in return environment makes complex. The passion of work or task reflects negatively although completing it.

One of biggest challenges faced by the health care profession in the world is patient safety. In the health care field adverse events leading 8th mortality percentage in the united stated then other causes of death (Manojlovich \& DeCicco, 2007) Nursing professionals are the biggest force to solve health-related concerns of the patient so reliability lies open them. Interruptions in nursing practice create huge opportunity for developing risky environment. The soul and mental calmness of nurses bring safe practices reduces the chance of errors. The nurses are vital force who ensure safety.

Interruption is considered to be part of the workplace. The nursing profession responsibility and reliability are of high concerns because it deals with life of human beings. Although the reboots performing extensive manpower replacing human beings there is a difference in machine and structure of emotions and feeling. The interruptions are many faced in single shift increases in hundreds. Dealing with them many times makes fatigued so the level of compliance with competence gets worse patient relying on nurses to become risky unfortunately can face wrong medication, wrong procedure, or any other type of complication.

There are different interruptions which come across as obstacle but differs that many health care providers cannot identify. They had never sensed them as a workstream breaker. A source can be environment, patients, administrative round, sudden effect of policy, communication, noise. The noise can be from an environment like successive beeping from the machine. So, the interruption related to the professional activity is somewhat considered as part of jobs, but the matter effect creates hindrance in performing the structured activity. Intrusion in the nursing work environment can be the noxious effect on patient's life (Hall, Pedersen, \& Fairley, 2010). 
International Journal of Health, Medicine and Nursing Practice ISSN 2710-1150 (Online)

Vol. 3, Issue No. 2, pp 17- 35, 2021

$\underline{\text { www.carijournals.org }}$

Nursing is the pioneer of health care industry, appreciation given makes level monstrous. This profession carries a risky task of dealing lives likes non other professionals who have the huge authority of providing, educating, counseling and advocating the right of humans. In the other way round interruptions are considered to be a part of professional life. In health care facility all member is defined with their job entitlement but many tasks related interruption directly or indirectly affect every member of the team. In renowned organization have committed right of patients in such a way that everyone in the team including nurses, doctor, health assistance and cleaners or any member have given his/her best to sort issues or directing in such an impressive way. At some stage, it gets the title of interruption.

Interruptions are part of the health care community either man-made or technical or environment, as far as human made concerns in many organizations attendant guidance is available, but what makes difference is the level of understating and level of literacy. Hospital is place which makes panic relatives but also staff, because all contribute to save the damage or prevent from worsening. The relatives of patient education are of prime importance either is a demonstration, video-based or visual standee. The understanding of rules and regulation of attendants makes the system effective as far as repeated interruptions are concerns. Attendants' perception lies that their concerns ought to be replied in a well-mannered way in spite any situation. Significance is best observed by a person can predict hypothetical to the upcoming problem. So better interpretation can help out the problem from both concerns.

The culture makes the environment to understand what is going on. Pakistan community believes that more exertion and exaggeration can emphasize better outcomes. The unwanted pressure on medical staff put under pressure which elevates the level of agitation and frustration. This is a point where intervention can become very dangerous for the patient and health care providers. The frustration level raises directly increases the risk for the patient. There is a need of understanding and committing the nature of human beings who cannot give the best product under stress and anxiety. Predicted Outcome Value theory explains the predicted outcome of interruptions by making the decision whom to respond or avoid to prevent errors (Sunnafrank, 1986).

\section{Problem Statement}

Nursing workplace performance extensively affected by human fallibilities, distractions and interruptions likelihood create errors by diverting the attention of human beings by influencing memory lapses. Interruptions are not identified as an obstacle in the clinical place.(Alvarez \& Coiera, 2005) explained that nurses were interrupted 26 times per hour. 89.9 to $90 \%$ of interruptions resulted in negative consequences loss of concentration and delay in treatment plan (Hall, Pedersen, et al., 2010). The study will elaborate on the problem of nursing related to interruptions. The study will create awareness in nurses about interruptions which consequently decreases the problem of nurses in clinical areas. Enhance the strategies to prioritize the task. Nurses need critical thinking, reasoning, and prioritization of task to prevent professional 


\section{Objective}

To assess the knowledge, attitude and practice regarding nursing interruption nurses working in tertiary care hospitals. The measurement of knowledge, attitude, and practice will be done by questionnaire

\section{Hypothesis}

\section{Null Hypothesis Ho:}

There is no relationship of between nurse's knowledge, attitude, practice and nursing interruptions.

\section{Alternative Hypothesis $\mathrm{H}_{1}$ :}

There is a relationship of between nurse's knowledge, attitude, practice and nursing interruptions.

\section{Operational Definition}

\section{Interruption}

Interruption can be defined as the responder distract the attention of health care workers and purposefully need to refocus on activity.

\section{Practice}

Periods arranged for the determination repeating and act development are called practice. Practices are negative and positive.

\section{Knowledge}

Knowledge is the awareness of people of the hospital regarding extravasation care. Complication and prevention.

\section{Practice}

Doing something usual, usual or expected, or a way to do something

\section{LITERATURE REVIEW}

Safety on care is interrupted if care provider is interrupted. A study shows 33 nurses were observed by two nurses for three hours, It was closely observed that almost all nurses were interrupted due to interruptions 7.85 times per hour(Prates \& Silva, 2016). The safety of the level of the patient from nurses' work effects greatly leading to errors. Making susceptible patients for risk need serious intervention creating a barrier in split the safety zone.

The interruption exists all over the health care system research shows different categories of patient needs nursing care accordingly which become the cause of contributing findings nursing leaders help the situations by improving the system reduces the interruptions leading to patient safety concerns like treatment delays and distracting attention. Interdisciplinary-based approach to manipulate the organization design to lower down damage done by interruptions (Hall, FERGUSON-PARÉ, et al., 2010). 
International Journal of Health, Medicine and Nursing Practice ISSN 2710-1150 (Online)

Vol. 3, Issue No. 2, pp 17- 35, 2021

$\underline{\text { www.carijournals.org }}$

Moreover, interruptions create sometimes miserable situation cost them a life even. Interruptions not only decrease the productivity but also influence the risk for clients. Consequently, increase the workload that leads to mortality rates (Fasoi et al., 2021).

Knowledge of nurses about interruption quite confused interruption is defined as draws someone concentration away from whom responder purposeful focusing. The best can be exemplified by if a person purposely doing some tasks interrupted by a source like communication, ringing phone bell, called by someone to achieve goal have to focus once again. Nurses face many challenges at work place. The nurse's interruptions are somehow not deliberatively projected. Interruption created hindrance in performing job. The interruption in clinical work creates an obstacle in performing smooth duty. Interruption at the workplace so frequent that makes a targeted task impossible. Mental, psychological and emotional disturbance. Nursing procedure effected extensively during insertion of peripheral line, central line pressure, signing in a procedure, or administering medication. (Alvarez \& Coiera, 2005) emphasized that it has been observed that almost 26-time nursing staff was interrupted in every hour.

Compliance of nursing effectiveness greatly achieved by pour contribution with soul and mind. Health care providers always work in the collaborative pattern so if one person made to delay ultimately whole force affected the doctor and nurses who work in critical care and emergency departments estimated interrupted 10 times in a hour (Brixey et al., 2008).

The simplicity of task has lessened the chance to be affected by an external force while complex task makes the task susceptible to diversion of concentration of worker.

Interruption could influence the simplicity of tasks easier while in a tough job, it triggers the influence in negative ways. Disruption in the task may affect required compliance and in critical situations, it becomes very risky to get the job done. In the case of trainee health care provider interruption become more destructive in completing the clinical procedure (Speier, Vessey, \& Valacich, 2003).

The interruptions impact negative in any clinical settings takes more time to complete the task. Need more skill to complete the task and as well deal with interruptions psychological skill, enhanced decision making and competent (Li, Magrabi, \& Coiera, 2012). The clinical setting of health care professionals is very hectically busy, demanding, attention and time consuming, objective to achieve at workplace require undivided attention to achieve the task. Repetitive interruption and distraction in work make the task more complex, leading to frustration result in the effective health of the patient. Interruptions may include beeping of the instrument, phone call, paging, administrative interference, communication and noise etc. put more burden already occupied health care providers (Rivera-Rodriguez \& Karsh, 2010).

Study about distraction and interruption in operation theatre among novice nurses concluded under simulated conditions observed that attention distractions promote leading to errors in clinical health settings. The environment of operating room normally very critical like handling instrument and counting of instrument, controlling of bleeding and proper handling the depth of anesthesia require high level of concentration minute distraction and interruption can result in sentinel events. 
International Journal of Health, Medicine and Nursing Practice ISSN 2710-1150 (Online)

Vol. 3, Issue No. 2, pp 17- 35, 2021

$\underline{\text { www.carijournals.org }}$

The surgical errors caused in $8(44 \%)$ procedures in total 18 procedure while 1 of them distraction and interruption were 6\% (Feuerbacher, Funk, Spight, Diggs, \& Hunter, 2012).

The nursing work is affected by nursing interruption. Nursing interruption is directly related to task-related distractions. Nursing interruptions are subsequently affected by medical diagnosis. Nurses are the persons who directly provide care to the patients' medical professionals are not frequent direct contact. If an implementation is delayed leads to poor prognosis of the patient. The reflection of health care provider includes nurse, doctors and paramedical staff remains unsatisfactory. Distraction and interruptions not only waste time but also cost heavily speed and precision. Successive diversion in clinical practice cannot guarantee the quality of care.

The management and administrative bodies are the ones who's responsible to counter the job restriction and irritable phase in clinical settings. While making the policy and procedure with the subject of distraction calculated risk of making or chance of bad events considered to comply with making perception better of nursing profession. As far nursing profession concerns in Pakistan where nurses are already insufficient to provide care as the quantity of population exists. The better environment at workplace can bring better outcomes. The training regarding dealing with interruption and distraction should be enhanced to avoid errors at the workplace and increase the quality of care in nursing.

Observation of time of interruption and severity of task within which nurses face interruptions. The work severity is divided into three levels include low, medium and high task severity levels. The study explains that nurses working intensive care units face interruption in performing medium severity tasks 50\% which includes documentation e.g., while performing high severity tasks performing clinical procedures is $35 \%$ and in low severity tasks $14 \%$ include general care. The study broadly emphasizes the importance of task require high attention rate of interruption is high so chance of encountering the error is quite high. In critical care settings patients prone to get sentinel events, there is a need of determination to deal with interruptions.

The interruptions at the workplace are of different types and categories are of various. Interruptions while administering medications quite high in numbers. Administering drugs through any route are of equal importance with perception consequences toward negligence. While administering medication 298 interruptions were recorded in 945 medications as an observational study. There is one interruption in every 3.2 medication given. Study also concluded that higher interruption was created by responding on telephone which distracted attention than any other distraction (Palese, Sartor, Costaperaria, \& Bresadola, 2009). While medication administering process rate of interruption was more 11 hundred and about $50 \%$ of them was severing high chance of compromising the safety of the patient (Getnet \& Bifftu, 2017). The interruption is a type of distraction and distractions are part of the job. So important for a nurse to differentiate the difference between valid and invalid interruption. The distinction in the type of interruptions makes the difference either to cope or to avoid (Interruptions: 10 Ways to Minimize Stops and Starts, 2020). 
International Journal of Health, Medicine and Nursing Practice ISSN 2710-1150 (Online)

Vol. 3, Issue No. 2, pp 17- 35, 2021

$\underline{\text { www.carijournals.org }}$

\section{MATERIAL AND METHODS}

Study design: The study design quantitative cross-sectional will be used to collect data. The reason for selecting study design is population are nurses they working in many at same time, ought to measure the outcome of exposure, prevalence and experience prime importance of study. The nurse's demographic information may variance with knowledge attitude and practice. The prevalence of study problem is common so single-time data can be used to generalize the conclusion of study without manipulation.

Settings: Tertiary care hospitals

Sample size: 01, March,2021- 15, April,2021

Sampling technique: Convenient sample Technique will be used to collect data

Sample selection: The tertiary care hospital selected to collect data number of nurses working there are more in number so generalization of data on the community of nurses

Target population: population to be selected for study is staff nurses working in tertiary care hospital Lahore

Inclusion criteria: inclusion criteria include nurses should be licensed nurses, providing direct clinical care to patients, maintain a normal cognition level of interpretation, understanding information and willing to participate. Inclusion criteria would make data clear and concise related to problem of study. Validated data would reflect real responses to generalize the information.

Exclusion criteria: Exclusion criteria include nurses working in centre of a sterile supply store, working in drug distribution or any not providing direct care to patients. Any who does not want to be part of study.

\section{Sample Size:}

Sample size calculated as considering confidence level 1- $\alpha 95 \%$,

Anticipated population proportion p:0.708

Absolute precision required d:0.08

Sample size $(n)=115$

\section{Data collection tool:}

A tool used for study a well-formatted adopted questionnaire used in study (Xie et al., 2020). The aim to determine the information regarding nursing interruptions among nurses working in Pakistan tertiary care centres. The questionnaire contains information regarding information sociodemographic data then questionnaire including knowledge, attitude and practice questions total number in 26 . The questionnaire was viewed about content by 12 experts and the validity index calculated was .83 , having three dimensions knowledge attitude and practice.

Socio-demographic information characteristics include age, gender, marital status, departments, employment, employment type, hospital level, position enter level into nursing, highest education, income, night shift, leaders' attentions and nursing interruption experience. 
Questionnaire on knowledge about the concept of interruption in nursing scoring starting from no understanding equal to 1 and strong understanding equal to 5 score total question regarding knowledge is 10 . The practice of nurse's assessment by questions which are total in number 9 , answers graded in 5 levels from strongly agree to strongly disagree.

The questionnaire to explore the attitude is total of 7 in number scoring from $1-4,1$ is equal to never and the maximum is 4 comes equal to always.

\section{Significance of Study:}

the study will help to explore the knowledge, attitude and practice of nurses about interruptions are faced directly and indirectly.

The readers will have the advantage of understanding about nursing interruptions can contribute themselves by using prioritization and improving their practice to avoid interruptions.

The higher administration will have clear understating empowers their nurses to conduct education on nursing interruptions. This creates an environment to help nurses to avoid by preventing risk to the life of patients

\section{Ethical considerations:}

- Written informed consent (attached) will be taken from all the participants.

- All information and data collection will be kept confidential.

- Participants will remain anonymous throughout the study.

- The subjects will be informed that there are no disadvantages or risks on the procedure of the study.

- They will also be informed that they will be free to withdraw at any time during the process of the study.

- They will participate in research study voluntary, will not be penalized if they decide to leave after giving consent.

\section{Data collection procedure:}

The data collected through random sampling technique as based on probability sampling. A constructed questionnaire will be used to collect data from a target population of staff nurse's tertiary care hospital in Lahore. Participants will be informed about the purpose of the study. Entitled clearly will have the right to leave participation in study. Adequate time will be given then to properly filling the questionnaire receiving back to reduce biasness.

- categorical variables are age, gender then categorical variable include experience, level of education while joining nursing profession, current education level, hospital type, position, training about nursing interruption, night shift duty in past for 4-month duty, leader attention, marital status, employment type and experience of the job.

- Dependable variable is nurses' interruptions

- Undependable variable knowledge, attitude and practice 
International Journal of Health, Medicine and Nursing Practice ISSN 2710-1150 (Online)

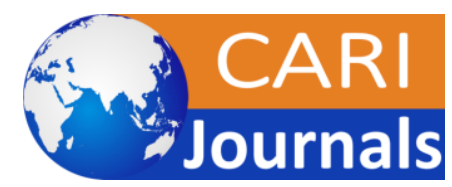

Vol. 3, Issue No. 2, pp 17- 35, 2021

www.carijournals.org

\section{Data analysis:}

The collected data analysed by using SPSS 25.0 window version. $\mathrm{P} \leq 0.05$ which would be significant in rejecting null hypothesis and affirms a significant relationship variable of study, data will be entered to confirm the completeness of questionnaire by the respondents.

Descriptive analysis will include mean, standard deviation and percentages (Age, gender, marital status, experience, education while joining nursing, current education, hospital type, employment type, interruption training).

Inferential Statistics include application of t-test, and ANOVA, Pearson correlation to identify the relationship among the means of more than two groups

\section{FINDINGS AND PRESENTATION}

Characteristics demographically illustrate (Table 1) that data collected from 115 participants through questionnaire. Data collected by gender wise was male 20(17.6\%) and female 95(82.4\%), majority of candidates were experienced ranging from 3-5 years (42.6\%) and 11-15 years (32.6\%), major age group 26-30 years (49.6\%), permanent employee type 87\%, 61.1\% employee faced interruption during their career. Respondent belongs low designation as a general nurse $(86.1 \%)$. Leader of team attention (Table 2) requires opinion was (63.5\%). knowledge based questionnaire item 1(basic understanding about nursing interruptions) quite high 10.2\%., item 7(The relationship between nursing interruption and medical outcomes) lower information $15.7 \%, 8.7 \%$ did know how to cope with nursing interruptions.

Table 1: Demographic Characteristics

\begin{tabular}{llllll}
\hline Gender & Frequency & Percentage & Frequency & Percent \\
\hline Male & & \multicolumn{2}{c}{ Standardized Training } & \\
Female & 20 & 17.4 & Yes & 73 & 63.5 \\
Department & 95 & 82.6 & No & 42 & 36.5 \\
Medical & 15 & 13 & Interruption experience & & \\
Surgical & 24 & 20.9 & No & 71 & 61.7 \\
Emergency & 26 & 22.6 & Leader attention & 42 & 36.5 \\
Peads & 5 & 4.3 & Fully agree & 20 & \\
Gynae & 3 & 2.6 & Agree & 73 & 17.4 \\
ICU & 36 & 31.3 & Not sure & 19 & 63.5 \\
OR & 3 & 2.6 & Disagree & 2 & 16.5 \\
Others & 3 & 2.6 & Strongly disagree & 1 & 1.7 \\
Marital Status & & & Position & & 0.9 \\
Married & 39 & 33.9 & Registered Nurse & 99 & 86.1 \\
Unmarried & 75 & 6.2 & Infection control nurse & 7 & 6.1 \\
Divorced & 1 & 0.9 & Supervisor & 6 & 5.2 \\
Widowed & 0 & 0 & Head nurse & 3 & 2.6 \\
\hline
\end{tabular}


International Journal of Health, Medicine and Nursing Practice ISSN 2710-1150 (Online)

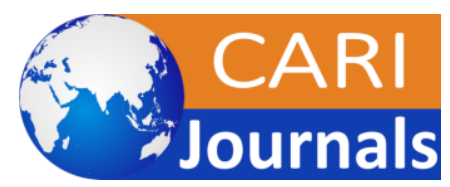

Vol. 3, Issue No. 2, pp 17- 35, 2021

www.carijournals.org

\section{Experience}

Less than 3 years 10

3-5 years 49

6-10 years 7

11-15 years 37

16-20 years 5

Equal or more

than 20 years 7

Age

Less than 25 years 32

26-30 years 57

31-35 years 20

36-40 years

41-45 years

Employment

type

Permanent 101

Contract
14

\section{7}

42.6

6.1

32.2

4.3

6.1

27.8

49.6

17.4

0.9

4.3

5

\section{Level of education entering} profession

Matric

25

21.7

Intermediate

62

53.9

Graduation

24

20.9

Master

6.1

Highest level of education

Matric

8

7

Intermediate

33

28.7

Graduation

55.7

Master

8.7

Night shift more than 4 months

Yes

80

69.6

NO

35

30.4

\section{Hospital Type}

$87.8 \quad$ Secondary 42

36.5

Tertiary

73

63.5

Table 2: Knowledge statements regarding nursing interruption among nurses

\begin{tabular}{|c|c|c|c|c|c|c|c|}
\hline & $\begin{array}{l}\text { Knowledge } \\
\text { Statement }\end{array}$ & Mean \pm SD & $\begin{array}{l}\text { Don't } \\
\text { know }\end{array}$ & $\begin{array}{l}\text { Have } \\
\text { heard }\end{array}$ & $\begin{array}{c}\text { Generally } \\
\text { understoo } \\
\text { d }\end{array}$ & $\begin{array}{l}\text { Comparati } \\
\text { vely } \\
\text { understoo } \\
\text { d }\end{array}$ & $\begin{array}{c}\text { Well } \\
\text { understoo } \\
\text { d }\end{array}$ \\
\hline 1 & $\begin{array}{l}\text { The understanding } \\
\text { of nursing } \\
\text { interruption } \\
\text { Sources of nursing }\end{array}$ & $2.90 \pm 1.165$ & $\begin{array}{c}12(10 . \\
4 \%) \\
9(7.8 \%\end{array}$ & $31(31 \%)$ & $46(40 \%)$ & $9(7.8 \%)$ & $17(14.8 \%)$ \\
\hline 2 & $\begin{array}{l}\text { interruptions } \\
\text { Types of nursing }\end{array}$ & $2.851 \pm 028$ & ) & $33(28.7)$ & $49(42.6 \%)$ & $14(12.2 \%)$ & $10(8.7 \%)$ \\
\hline 3 & $\begin{array}{l}\text { interruptions } \\
\text { Consequences of } \\
\text { nursing }\end{array}$ & $2.96 \pm 1.119$ & $8(7 \%)$ & $25(21.7 \%)$ & $43(37.4 \%)$ & $24(20.9 \%)$ & $14(12.2 \%)$ \\
\hline 4 & $\begin{array}{l}\text { interruptions } \\
\text { Common types of } \\
\text { nursing interruption }\end{array}$ & $3.272 \pm 253=$ & $\begin{array}{l}9(8 \%) \\
7(6.1 \%\end{array}$ & $2521.7 \%)$ & $43(20.9 \%)$ & $24(20.9 \%)$ & $14(12.2 \%)$ \\
\hline 5 & $\begin{array}{l}\text { in nursing work } \\
\text { What nursing work }\end{array}$ & $3.0 \pm 1.092$ & ) & $33(28.7 \%)$ & $42(36.5 \%)$ & $19(16.5 \%)$ & $14(12.2 \%)$ \\
\hline 6 & $\begin{array}{l}\text { is affected by } \\
\text { nursing interruption } \\
\text { The relationship } \\
\text { between nursing }\end{array}$ & $3.13 \pm .941$ & $\begin{array}{c}4(3.5 \% \\
)\end{array}$ & $21(18.3 \%)$ & $57(49.6 \%)$ & $22(19.1 \%)$ & $11(9.6 \%)$ \\
\hline 7 & $\begin{array}{l}\text { interruption and } \\
\text { medical outcomes. }\end{array}$ & $2.90 \pm 1.155$ & $\begin{array}{c}18(15 . \\
7 \%)\end{array}$ & $18(15.7 \%)$ & $46(40 \%)$ & $23(20 \%)$ & $10(8.7 \%)$ \\
\hline
\end{tabular}


International Journal of Health, Medicine and Nursing Practice ISSN 2710-1150 (Online)

Vol. 3, Issue No. 2, pp 17- 35, 2021

$\underline{\text { www.carijournals.org }}$

\begin{tabular}{|c|c|c|c|c|c|c|c|}
\hline & Effect of nursing & & & & & & \\
\hline 8 & $\begin{array}{ll}\text { interruptions } & \text { on } \\
\text { patient safety } & \end{array}$ & $3.48 \pm 1.165$ & $\begin{array}{c}7(6.1 \% \\
)\end{array}$ & $14(12.2 \%)$ & $39(33.9 \%)$ & $27(23.5 \%)$ & $28(24.3 \%)$ \\
\hline 9 & $\begin{array}{l}\text { How to cope with } \\
\text { nursing } \\
\text { interruptions? }\end{array}$ & $3.13 \pm 1.088$ & $\begin{array}{c}10(8.7 \\
\%)\end{array}$ & $16(13.6 \%)$ & $53(46.1 \%)$ & $21(18.3 \%)$ & $15(13 \%)$ \\
\hline & $\begin{array}{l}\text { Effect of nursing } \\
\text { interruptions on }\end{array}$ & & $7(6.1 \%$ & & & & \\
\hline 10 & nurses' emotion. & $3.68 \pm 1.151$ & ) & $12(10.4 \%)$ & $22(19.1 \%)$ & $44(38.3 \%)$ & $30(26.1 \%)$ \\
\hline
\end{tabular}

As far as attitude concerns (Table 3 ) item 1 (I think the management of nursing interruptions events is very important for patient safety) $8.7 \%$ nurses strongly disagree, item 2(I think managing nursing interruptions can demonstrate my ability to work) $17.4 \%$ believed no relation between nursing interruption and ability to work. 19.1\% nurses' item 6(Nurses should set aside some time for learning about nursing interruptions events) disagree about re-evaluate the circumstance to avoid damage impacted by interruptions. $25.2 \%$ item 7 (I think reducing nursing interruptions will improve my mood) disagree that interruption would not improve attention to work. Practice of nurses (table 4) regarding dealing interruptions item 3 (Guiding patients and family members to participate in nursing interruptions management) $10.2 \%$ had never understood conditions to to make environment comfortable and 30.4\% tried often, (item 6) $14.8 \%$ had not participated training program to reduce interruptions, while sometime $34.8 \%$ participated in nursing interruption. (Item 7) interventional management of nursing intervention sometimes (41\%).

Table 3: Attitude statements regarding nursing interruption among nurses

\begin{tabular}{|c|c|c|c|c|c|c|c|}
\hline & Attitude Statement & $\begin{array}{c}\text { Mea } \\
\text { n } \\
\pm \text { SD }\end{array}$ & $\begin{array}{l}\text { Strongly } \\
\text { disagree }\end{array}$ & $\begin{array}{l}\text { Disa } \\
\text { gree }\end{array}$ & $\begin{array}{c}\text { General } \\
\text { ly, } \\
\text { agree }\end{array}$ & $\begin{array}{c}\text { Comparat } \\
\text { ively } \\
\text { agree }\end{array}$ & $\begin{array}{c}\text { Strong } \\
\text { ly } \\
\text { agree }\end{array}$ \\
\hline & I think the management of nursing & 3.69 & & & & & \\
\hline & ions events is very important for & \pm 1.1 & $10(8.7 \%$ & $7(6.1$ & $19(16.5$ & & $24(20.9$ \\
\hline \multirow[t]{3}{*}{1} & patient safety & 11 & ) & $\%)$ & $\%)$ & $55(47.8 \%)$ & $\%)$ \\
\hline & & 3.71 & & $20(1$ & & & \\
\hline & I think managing nursing interruptions can & \pm .97 & & $7.4 \%$ & $18(15.7$ & & $17(14.8$ \\
\hline 2 & demonstrate my ability to work & $\begin{array}{c}1 \\
2.89\end{array}$ & $4(3.5 \%)$ & ) & $\%)$ & $56(48.7 \%)$ & $\%)$ \\
\hline 3 & $\begin{array}{l}\text { I believe that preventing nursing interruptions } \\
\text { can improve the quality of nursing wo }\end{array}$ & $\begin{array}{c} \pm .97 \\
1\end{array}$ & $3(2.6 \%)$ & $\begin{array}{l}10(8 . \\
7 \%)\end{array}$ & $\begin{array}{c}21(18.3 \\
\%)\end{array}$ & $50(43.5 \%)$ & $\begin{array}{l}31(27 \\
\%)\end{array}$ \\
\hline & $\begin{array}{l}\text { Nursing managers should be fully aware of } \\
\text { the importance of managing nursing }\end{array}$ & $\begin{array}{l}4.17 \\
\pm .78\end{array}$ & & $4(3.5$ & $22(19.1$ & & $44(38.3$ \\
\hline 4 & interruptions & $\begin{array}{c}7 \\
3.92\end{array}$ & $2(1.7 \%)$ & $\%)$ & $\%)$ & $43(37.4 \%)$ & $\%)$ \\
\hline 5 & $\begin{array}{l}\text { I think every nurse should learn how to deal } \\
\text { with nursing interruptions }\end{array}$ & $\begin{array}{c} \pm 1.0 \\
10 \\
3.71\end{array}$ & $5(4.3 \%)$ & $\begin{array}{c}4(3.5 \\
\%) \\
22(1\end{array}$ & $\begin{array}{c}29(25.2 \\
\%)\end{array}$ & $39(33.9 \%)$ & $\begin{array}{c}38(33 \\
\%)\end{array}$ \\
\hline 6 & $\begin{array}{l}\text { Nurses should set aside some time for } \\
\text { learning about nursing interruptions events. }\end{array}$ & $\begin{array}{c} \pm .95 \\
5 \\
3.43\end{array}$ & $5(4.3 \%)$ & $\begin{array}{c}9.1 \% \\
) \\
29(2\end{array}$ & $\begin{array}{c}24(20.9 \\
\%)\end{array}$ & $49(42.6 \%)$ & $\begin{array}{c}15(13 \\
\%)\end{array}$ \\
\hline 7 & $\begin{array}{l}\text { I think reducing nursing interruptions will } \\
\text { improve my mood }\end{array}$ & $\begin{array}{c} \pm 1.0 \\
77\end{array}$ & $7(6.1 \%)$ & $\begin{array}{c}5.2 \% \\
)\end{array}$ & $\begin{array}{c}36(31.3 \\
\%)\end{array}$ & $22(19.1 \%)$ & $\begin{array}{c}21(18.3 \\
\%)\end{array}$ \\
\hline
\end{tabular}


International Journal of Health, Medicine and Nursing Practice ISSN 2710-1150 (Online)

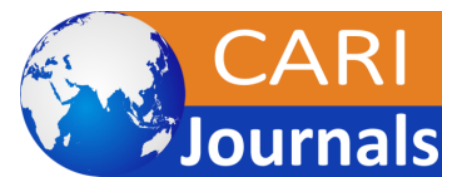

Vol. 3, Issue No. 2, pp 17- 35, 2021

WWW.carijournals.org

\begin{tabular}{|c|c|c|c|c|c|c|c|}
\hline \multirow[b]{3}{*}{8} & & 3.74 & & $12(1$ & & & \\
\hline & I want to change the nursing environment to & \pm 1.0 & & $0.4 \%$ & $26(22.6$ & & $29(25.2$ \\
\hline & reduce nursing interruptions & $\begin{array}{c}60 \\
3.86\end{array}$ & $4(3.5 \%)$ & ) & $\%)$ & $44(38.3 \%)$ & $\%)$ \\
\hline 9 & I always actively deal with nursing & \pm 0.9 & $4(35 \%)$ & $6(5.2$ & 22(19.1 & $53(461 \%)$ & $30(26.1$ \\
\hline
\end{tabular}

Table 4: Practice statements regarding nursing interruption among nurses

\begin{tabular}{llccccc}
\hline & & Mean & Someti & Usuall & alway \\
Practice Statement & \pm SD & Never & mes & y, & s \\
\hline & & $2.83 \pm 1$. & $7(6.2$ & $51 .(44$. & $23(20$ & $34(29$. \\
1 & Accurate identification of nursing interruptions at work. & 279 & $\%)$ & $3 \%)$ & $\%)$ & $6 \%)$ \\
& & $3.0 \pm 0.8$ & $3(2.6$ & $29(25.2$ & $48(41$. & $35(30$. \\
& & 16 & $\%)$ & $\%)$ & $7 \%)$ & $4 \%)$ \\
& Report nursing interruptions to superiors in time. & $2.78 \pm 0$. & $12(10$. & $35(30.4$ & $34(29$. & $34(29$. \\
& Guiding patients and family members to participate in & 989 & $2 \%)$ & $\%)$ & $6 \%)$ & $6 \%)$ \\
3 & nursing interruptions management. & $2.83 \pm 0$. & $5(4.3$ & $36(31.3$ & $47(40$. & $27(23$. \\
& & 837 & $\%)$ & $\%)$ & $9 \%)$ & $5 \%)$ \\
4 & Assist other colleagues in handling nursing interruptions & $2.72 \pm 0$. & & $43(37.4$ & $37(32$. & $27(23$. \\
& Response to nursing interruptions according to the & 904 & $8(7 \%)$ & $\%)$ & $2 \%)$ & $5 \%)$ \\
5 & requirements of superiors & $2.58 \pm 1$. & $17(14$. & $40(34.8$ & $32(27$. & $26(22$. \\
& & 00 & $8 \%)$ & $\%)$ & $8 \%)$ & $6 \%)$ \\
6 & Participate in training related to nursing interruptions. & $2.83 \pm 0$. & $5(4.3$ & $47(40.9$ & $25(21$. & $38(33$ \\
& Participation in Management Intervention of Nursing & 945 & $\%)$ & $\%)$ & $7 \%)$ & $\%)$ \\
7 & Interruptions. & & & & &
\end{tabular}

Table 5: Knowledge, attitude, and practices regarding nursing interruption among nurses

\begin{tabular}{|c|c|c|c|c|c|c|c|c|c|c|}
\hline \multirow[b]{2}{*}{ Variable } & & \multicolumn{3}{|c|}{ Knowledge } & \multicolumn{3}{|c|}{ Attitude } & \multicolumn{3}{|c|}{ Practice } \\
\hline & & $\begin{array}{l}\text { Low } \\
\text { satisf } \\
\text { action } \\
\end{array}$ & $\begin{array}{l}\text { Averag } \\
\text { e } \\
\text { satisfac } \\
\text { tion } \\
\end{array}$ & $\begin{array}{l}\text { High } \\
\text { satisfa } \\
\text { ction }\end{array}$ & $\begin{array}{l}\text { Low } \\
\text { satisf } \\
\text { action }\end{array}$ & $\begin{array}{l}\text { averag } \\
\text { e } \\
\text { satisfac } \\
\text { tion } \\
\end{array}$ & $\begin{array}{l}\text { High } \\
\text { satisfa } \\
\text { ction }\end{array}$ & $\begin{array}{l}\text { Low } \\
\text { satisf } \\
\text { action }\end{array}$ & $\begin{array}{l}\text { Averag } \\
\text { e } \\
\text { satisfac } \\
\text { tion } \\
\end{array}$ & $\begin{array}{l}\text { High } \\
\text { satisfa } \\
\text { ction } \\
\end{array}$ \\
\hline \multirow{3}{*}{ Gender } & & & & & 12.17 & & & 10.40 & & \\
\hline & Male & $3.47 \%$ & $8.69 \%$ & $5.21 \%$ & $\%$ & 0 & $5.20 \%$ & $\%$ & $4.34 \%$ & $2.60 \%$ \\
\hline & & & & 26.08 & 60.80 & & 21.70 & 26.90 & & 30.30 \\
\hline \multirow{11}{*}{$\begin{array}{l}\text { Marital } \\
\text { status }\end{array}$} & Female & $33 \%$ & $23.47 \%$ & $\%$ & $\%$ & 0 & $\%$ & $\%$ & $25.20 \%$ & $\%$ \\
\hline & & & & 10.40 & 24.34 & & & 15.60 & & \\
\hline & Married & $8.60 \%$ & $14.70 \%$ & $\%$ & $\%$ & 0 & $9.50 \%$ & $\%$ & $8.69 \%$ & $9.56 \%$ \\
\hline & Unmarri & 26.90 & & 20.80 & 47.80 & & 17.39 & 21.70 & & 23.47 \\
\hline & ed & $\%$ & $17.30 \%$ & $\%$ & $\%$ & 0 & $\%$ & $\%$ & $20 \%$ & $\%$ \\
\hline & Divorced & $0.86 \%$ & $0 \%$ & $0 \%$ & $1.15 \%$ & 0 & $0 \%$ & $0 \%$ & $0.86 \%$ & $0 \%$ \\
\hline & $\begin{array}{l}\text { Less } \\
\text { than } 3\end{array}$ & & & & & & & & & \\
\hline & & $3.47 \%$ & $1.73 \%$ & $3.47 \%$ & $6.08 \%$ & 0 & $2.60 \%$ & $3.40 \%$ & $2.60 \%$ & $2.60 \%$ \\
\hline & & 16.50 & & 13.04 & 32.10 & & 10.43 & 14.70 & & 12.10 \\
\hline & $\begin{array}{l}3-6 \text { years } \\
6-10\end{array}$ & $\%$ & $13.04 \%$ & $\%$ & $\%$ & 0 & $\%$ & $\%$ & $15.60 \%$ & $\%$ \\
\hline & years & $1.73 \%$ & $3.47 \%$ & $0.86 \%$ & $8.08 \%$ & 0 & $0 \%$ & $2.60 \%$ & $2.60 \%$ & $0.86 \%$ \\
\hline
\end{tabular}


International Journal of Health, Medicine and Nursing Practice ISSN 2710-1150 (Online)

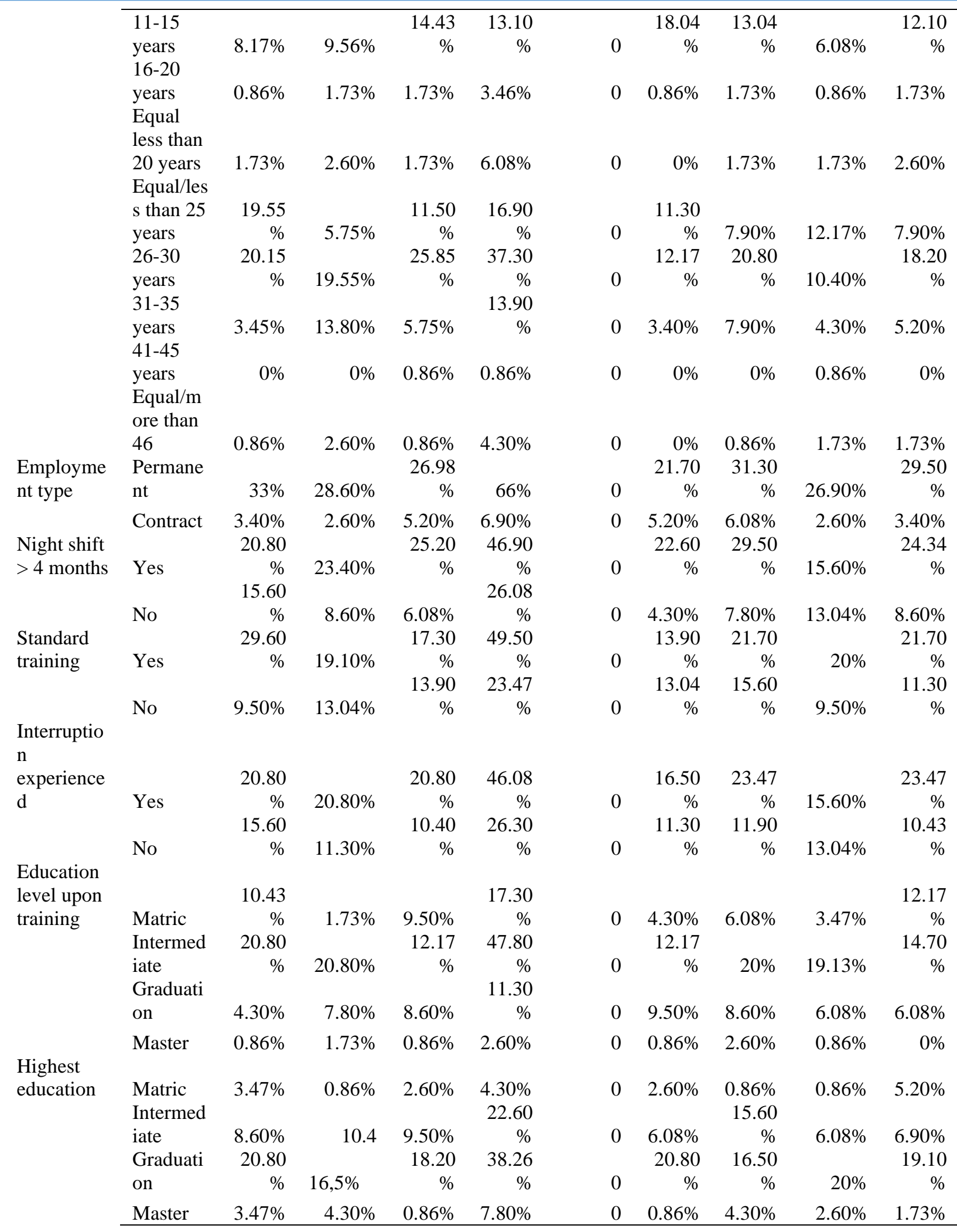


International Journal of Health, Medicine and Nursing Practice ISSN 2710-1150 (Online)

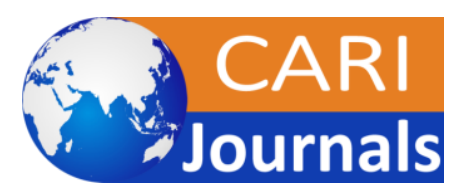

Vol. 3, Issue No. 2, pp 17- 35, 2021

WWW.carijournals.org

\begin{tabular}{|c|c|c|c|c|c|c|c|c|c|c|}
\hline & Register & 34.70 & & 26.08 & 62.60 & & 23.47 & 29.60 & & 31.30 \\
\hline Position & ed Nurse & $\%$ & $25.21 \%$ & $\%$ & $\%$ & 0 & $\%$ & $\%$ & $25.21 \%$ & $\%$ \\
\hline \multirow{11}{*}{$\begin{array}{l}\text { Leader } \\
\text { attention }\end{array}$} & $\begin{array}{l}\text { Infection } \\
\text { control } \\
\text { Supervis }\end{array}$ & $1.73 \%$ & $2.60 \%$ & $1.73 \%$ & $3.47 \%$ & 0 & $2.60 \%$ & $4.30 \%$ & $0.86 \%$ & $0.86 \%$ \\
\hline & $\begin{array}{l}\text { or } \\
\text { Head }\end{array}$ & $0 \%$ & $3.47 \%$ & $1.73 \%$ & $4.30 \%$ & 0 & $0.86 \%$ & $2.60 \%$ & $2.60 \%$ & $0 \%$ \\
\hline & Nurse & $0 \%$ & $0.86 \%$ & $1.73 \%$ & $2.60 \%$ & 0 & $0 \%$ & $0.86 \%$ & $0.86 \%$ & $0.86 \%$ \\
\hline & Full & & & & 12.17 & & & & & \\
\hline & agree & $1.73 \%$ & $6.08 \%$ & $9.50 \%$ & $\%$ & 0 & $5.20 \%$ & $6.08 \%$ & $3.40 \%$ & $7.80 \%$ \\
\hline & & 26.90 & & 18.20 & 47.80 & & 15.60 & 23.47 & & 22.60 \\
\hline & Agree & $\%$ & $18.20 \%$ & $\%$ & $\%$ & 0 & $\%$ & $\%$ & $17.30 \%$ & $\%$ \\
\hline & & & & & 11.30 & & 11.30 & & & \\
\hline & Not sure & $6.90 \%$ & $6.08 \%$ & $3.40 \%$ & $\%$ & 0 & $\%$ & $6.90 \%$ & $7.80 \%$ & $1.73 \%$ \\
\hline & $\begin{array}{l}\text { Disagree } \\
\text { Strongly }\end{array}$ & $0 \%$ & $1.73 \%$ & $0 \%$ & $1.73 \%$ & 0 & $0 \%$ & $0.86 \%$ & $0.86 \%$ & $0 \%$ \\
\hline & Disagree & $0.86 \%$ & $0 \%$ & $0 \%$ & $0 \%$ & 0 & $0.86 \%$ & $0 \%$ & $0 \%$ & $0.86 \%$ \\
\hline
\end{tabular}

The level of knowledge is relatively (table 5) gender-based level of education female had lower level of knowledge (33\%), attitude (60\%), the practice had high satisfactory education (30.3\%). Experience 11-15 years increased level of education about KAP. Age group of nurses from 26-30 years had higher degree of KAP. Graduation nurses with improved experience and education as compare to level of education upon entering profession improved and fresh nurses and interruption experienced proclaims high degree of knowledge attitude and practice.

The means of knowledge attitude and practices respectively $31.2957 \pm 7.21229,33.1478 \pm$ $5.68507,19.5826 \pm 3.86841$. the collective mean and standard deviation of knowledge attitude and practice $84.0261 \pm 16.76577$. Questionnaire scoring minimum to maximum extends from (26123). The scoring calculated from by frequency considering their median then projecting values $(1=33,2=66,3=100)$. The mean score of KAP correct was about $69 \%$. The total scoring of of KAP was significantly $(\mathrm{P}<0.05)$ nurses includes independent variables age, experience, training, interruption experience, leader attention, education while entering nursing profession and current education and experience of nigh duty in their career.

The test for distribution was normal in identification. The relationship among variable includes interruption training, exposure to interruption, experience, designation, level of education while entering nursing and current state makes significantly $(\mathrm{p}<.05)$. correlation among KAP demonstrates positive direction with the help of value of coefficient of efficient. KAP between themselves influences significantly $(\mathrm{P}<.05)$. The association defers by chi square between demographic data and KAP $(\mathrm{P}<.03)$. Pearson correlation found among with significance value $(\mathrm{P}<0.05)$ in significant direction age, experience, designation, night shift, interruption, training about dealing interruption, level of education entering education, later education gained, leader attention predictor in relation with KAP.

There is significant $(\mathrm{p}<0.05)$ relationship between knowledge and attitude as confirmed by Pearson correlation as well as there is positive correlation defines positive direction in criterion variable. ANOVA test also magnifies the relationship among knowledge attitude and practice with significant values $(\mathrm{p}<0.05)$. 
International Journal of Health, Medicine and Nursing Practice ISSN 2710-1150 (Online)

Vol. 3, Issue No. 2, pp 17- 35, 2021

www.carijournals.org

Table 5: Correlations

\begin{tabular}{lll|l|l}
\hline & & Knowledge & Attitude & practice \\
\hline knowledge & Pearson Correlation & 1 & $.300^{* *}$ & .037 \\
\cline { 2 - 5 } & Sig. (2-tailed) & & .001 & .696 \\
\cline { 2 - 5 } Attitude & $\mathrm{N}$ & 115 & 115 & 115 \\
& Pearson Correlation & $.300^{* *}$ & 1 & .168 \\
\cline { 2 - 5 } & Sig. (2-tailed) & .001 & 115 & .073 \\
\hline practice & $\mathrm{N}$ & 115 & .168 & 115 \\
& Pearson Correlation & .037 & .007 & 1 \\
\hline & Sig. (2-tailed) & .696 & 115 & 115 \\
\hline
\end{tabular}

**. Correlation is significant at the 0.01 level (2-tailed).

Table 6: Model of coefficient

\begin{tabular}{lc|c|c|c|c}
\hline & \multicolumn{2}{c}{$\begin{array}{c}\text { Unstandardized } \\
\text { Coefficients }\end{array}$} & $\begin{array}{c}\text { Standardized } \\
\text { Coefficients }\end{array}$ & & \multirow{2}{*}{ Sig. } \\
\cline { 2 - 4 } Model & $\boldsymbol{\beta}$ & Std. Error & Beta & t & Sig. \\
\hline $1 \quad($ Constant $)$ & 91.928 & 11.235 & & 8.182 & .000 \\
\hline
\end{tabular}

Table 7: Model summary

\begin{tabular}{|c|c|c|c|c|}
\hline Model & $\mathbf{R}$ & R Square & Adjusted R Square & $\begin{array}{c}\text { Std. Error of the } \\
\text { Estimate }\end{array}$ \\
\hline 1 & $.459^{\mathrm{a}}$ & .211 & .100 & 10.95439 \\
\hline
\end{tabular}

$\mathrm{R}$ square .0211 dependent variable cause variance in criterion variable about $21 \%$

\section{DISCUSSIONS, CONCLUSIONS AND RECOMMENDATIONS}

\section{Discussions}

The knowledge attitude and practice of interruption related to workplace are important significance. Knowledge about interruption would help to identify the information regarding distraction. The experience of nursing staff helps to react to distractions. The experienced nurses somehow manage to cope to some extent. Unexperienced nurses more susceptible to cope with problems so carries high prevalence to affect patient care. Those nurses not proper help training to tackle with knowledge and experience

The prime responsibility of nursing profession to confirm the safety of client while study shows $8.7 \%$ of questionnaire-based information denied the information regarding safety of client, 
International Journal of Health, Medicine and Nursing Practice ISSN 2710-1150 (Online)

Vol. 3, Issue No. 2, pp 17- 35, 2021

$\underline{\text { www.carijournals.org }}$

efficient strategy would require to counter interruptions can be better hand off communication and standardized tool. $42.6 \%$ respondents were age group of 3-5 years. The majority of population was from tertiary and performing permanent employee type. $36.6 \%$ nurses had not done any training regarding interruption in nursing profession and not experienced interruptions. $17.4 \%$ population not convinced to that they require leader attention. The majority of sample collected from young new nurses. Understanding about nursing interruptions did not know (10.2\%), Nursing profession contribute direct care to clients so understanding of conditions and complexities of environment is of prime importance to avoid compromise in care in regards of being scrutinized by nursing interruptions (Alvarez \& Coiera, 2005). Type of interruptions (21.8\%) study reflected that respondent just heard about while knowledge of types of nursing effects drastically to effect nurses task making them delay, unsafe and efficient performance. Interruption's cause Coordination concerns, communication and usability high percentage as study reflects that (33.9\%) people have just heard about statement but actually does not proper implementation of practices to reduce health care concerns.

Moreover, nursing interruption considerably effects medical outcome of patients, perception of assessing future outcome is competency of health care providers. The relationship can identify significant (cause, source and nurse reaction) and patients' outcomes either could be positive and negative. Patient significant relationship between source of interruption, task interrupted and the way nurses react to interruption (Johnson, Gillespie, \& Vance, 2018). Considering connection between nursing interruption reflection of positive and negative but does creates effect.

Interruption effects either positive or negative more important is the management of event of interruptions cause damage to safety of client. Better understanding and experience enhances tackle down the impact of interruption. Frequent interruptions in intensive care unit cause patient safety hazards, can be of any type could be alarm, human created interruption and protocol that are not alliance with department protocol. (Drews, Markewitz, Stoddard, \& Samore, 2019). Study reveals patient hazards created by mostly device alarms task that are not structured and nonadherence distraction influence.

The ability of nurse to control situation is very important need critical thinking and decision making to deliver against counter influence of interruptions. Nurse is vital part of professional conduct. The features nurse has against interruption overviewed putting food down and decline being interrupted also concludes professionalism, competent, keep focus, prioritizing task and compliance with disciplines (Laustsen \& Brahe, 2018).

Interruption's health care profession creates hindrance in providing effective and proper care. It induces mental distraction of nurses making them frustration leaving stamina underestimated condition. However, management in interruption eliciting relieving from stress and frustration to mental peace which ensures safety of patients.

Training of nurses had been major concerns of study. Nurses' ought to understand importance of training of nurses in management of interruptions on clinical place where not only health seeking persons on risk but providers are at greater risk to conduct mistake. Prime threshold of responsibility of leaders to emphasizes practical implementation of training of novice nurses. 
Shiferaw (2020) exclaims Leaders of nursing teams ought to impose workflow conductive by limiting the non-urgent interruptions and guide nurses to mitigate obstructions lead to patient harm cause experience to become worse. Training will adapt strategies to avoid interruption minimize the risk of healthy injury research (Klemets \& Evjemo, 2017) concluded that interruptions directly link performance variability to significantly unwanted and wanted interruptions. Health care resilience aligned by responding to non-avoidable distractions and avoiding unnecessary. So, technology assistive and nurse effort can avoid interruption consequently improve performance efficiency and patient safety. Thus minimizes the posing the risk to patient safety. Coping of nursing interruption important for nursing profession, safety of patient and quality of care (Laustsen \& Brahe, 2018). A study suggested that mindfulness helps nurses to cope with interruption (Beyea, 2014).

\section{Conclusions}

Knowledge attitude and practice prime parameters of confirming the quality of understanding and performance. The study concluded that nurses have a moderate level of knowledge attitude and practice $69 \%$. The knowledge and attitude positive coefficient correlation, enhance each other. Gender, increased academic qualification, attention of leader and experience correlation with KAP. Experience and age group 10-15 years possess a high degree of knowledge attitude and practice. There is a need of interruption management training moreover requiring leader attention. Basic understating about interruption on clinical place not considerably efficient. The dependent variable causes $20 \%$ variance in criterion variable.

\section{Recommendations}

Nursing interruptions are considerable distractions in clinical performance at work place. Strategies should be implemented revealing importance in nursing profession. Leader attention vital in enhancing awareness regarding this problem. Novice nurses can improve performance and reducing health related risk. Training of management of interruption also significant in lowering the risk to patient life.

\section{ACKNOWLEDGEMENT}

Thankful all students who participants in this study. I also thankful to the administration.

\section{REFERENCE}

Alvarez, G., \& Coiera, E. (2005). Interruptive communication patterns in the intensive care unit ward round. International journal of medical informatics, 74(10), 791-796.

Beyea, S. (2014). Interruptions and distractions in health care: improved safety with mindfulness. Maryland, USA: Agency for Healthcare Research and Quality.

Brixey, J. J., Tang, Z., Robinson, D. J., Johnson, C. W., Johnson, T. R., Turley, J. P., . . Zhang, J. (2008). Interruptions in a level one trauma center: a case study. International journal of medical informatics, 77(4), 235-241. 
International Journal of Health, Medicine and Nursing Practice ISSN 2710-1150 (Online)

Vol. 3, Issue No. 2, pp 17- 35, 2021

Www.carijournals.org

Drews, F. A., Markewitz, B. A., Stoddard, G. J., \& Samore, M. H. (2019). Interruptions and Delivery of Care in the Intensive Care Unit. Human Factors, 61(4), 564-576. doi:10.1177/0018720819838090

Fasoi, G., Patsiou, E. C., Stavropoulou, A., Kaba, E., Papageorgiou, D., Toylia, G., . . Kelesi, M. (2021). Assessment of Nursing Workload as a Mortality Predictor in Intensive Care Units (ICU) Using the Nursing Activities Score (NAS) Scale. International Journal of Environmental Research and Public Health, 18(1), 79.

Feuerbacher, R. L., Funk, K. H., Spight, D. H., Diggs, B. S., \& Hunter, J. G. (2012). Realistic distractions and interruptions that impair simulated surgical performance by novice surgeons. Archives of surgery, 147(11), 1026-1030.

Getnet, M. A., \& Bifftu, B. B. (2017). Work interruption experienced by nurses during medication administration process and associated factors, Northwest Ethiopia. Nursing research and practice, 2017.

Hall, L. M., FERGUSON-PARÉ, M., Peter, E., White, D., Besner, J., Chisholm, A., .. . Mildon, B. (2010). Going blank: factors contributing to interruptions to nurses' work and related outcomes. Journal of nursing management, 18(8), 1040-1047.

Hall, L. M., Pedersen, C., \& Fairley, L. (2010). Losing the moment: understanding interruptions to nurses' work. JONA: The Journal Of Nursing Administration, 40(4), 169-176.

Hall, L. M., Pedersen, C., Hubley, P., Ptack, E., Hemingway, A., Watson, C., \& Keatings, M. (2010). Interruptions and pediatric patient safety. Journal of pediatric nursing, 25(3), 167175.

Johnson, K. D., Gillespie, G. L., \& Vance, K. (2018). Effects of interruptions on triage process in emergency department: a prospective, observational study. Journal of nursing care quality, $33(4), 375$.

Klemets, J., \& Evjemo, T. E. (2017). Understanding Nurses' Strategies to Handle (Un)wanted Nurse Calls: A Resilience Perspective. CIN: Computers, Informatics, Nursing, 35(6), 289299. doi:10.1097/cin.0000000000000331

Laustsen, S., \& Brahe, L. (2018). Coping with interruptions in clinical nursing-A qualitative study. Journal of clinical nursing, 27(7-8), 1497-1506.

Li, S. Y., Magrabi, F., \& Coiera, E. (2012). A systematic review of the psychological literature on interruption and its patient safety implications. Journal of the American Medical Informatics Association, 19(1), 6-12.

Manojlovich, M., \& DeCicco, B. (2007). Healthy work environments, nurse-physician communication, and patients' outcomes. Am J Crit Care, 16(6), 536-543.

Monteiro, C., Avelar, A. F. M., \& Pedreira, M. d. L. G. (2015). Interruptions of nurses' activities and patient safety: an integrative literature review. Revista latino-americana de enfermagem, 23(1), 169-179. 
Palese, A., Sartor, A., Costaperaria, G., \& Bresadola, V. (2009). Interruptions during nurses' drug rounds in surgical wards: observational study. Journal of nursing management, 17(2), 185192.

Pepito, J. A., \& Locsin, R. (2019). Can nurses remain relevant in a technologically advanced future? International journal of nursing sciences, 6(1), 106-110.

Prates, D. d. O., \& Silva, A. E. B. d. C. (2016). Interruptions of activities experienced by nursing professionals in an intensive care unit. Revista latino-americana de enfermagem, 24.

Rivera-Rodriguez, A., \& Karsh, B.-T. (2010). Interruptions and distractions in healthcare: review and reappraisal. BMJ Quality \& Safety, 19(4), 304-312.

Speier, C., Vessey, I., \& Valacich, J. S. (2003). The effects of interruptions, task complexity, and information presentation on computer-supported decision-making performance. Decision sciences, 34(4), 771-797.

Sunnafrank, M. (1986). Predicted outcome value during initial interactions: A reformulation of uncertainty reduction theory. Human Communication Research, 13(1), 3-33.

Xie, J., Sun, Q., Tang, S., Ding, S., Zhong, Z., Zeng, S., . . Cheng, A. S. (2020). Knowledge, attitude and practice regarding nursing interruptions among Chinese nurses: A nationwide cross-sectional survey. International journal of nursing sciences, 7(1), 66-73. 